\title{
Violated Rights, Censured Memories: Histories of Violated Human Rights in Brazil and in the Southern Cone*
}

\author{
Anna Flávia Arruda Lanna Barreto \\ Federal University of Minas Gerais
}

This research aims to analyse the contents of Fundo Clamor, located at the Documentation and Scientific Information Centre-CEDIC, from the Pontifical Catholic University of São Paulo-SP, between the years of 1970 and 1992, as well as its contribution to the process of rescuing historical memory of child and teenager abduction, imprisonment, and torture in the course of military dictatorships in Brazil, Argentina, Uruguay, and Paraguay. The methodology used in this descriptive and qualitative research intends to take two directions: a bibliographical and a descriptive analytic documental research. Through the consultation and analysis of documents from Fundo Clamor (correspondence, denunciations, bulletins, and leaflets from Abuelas de la Plaza de Mayo, reports, writs of habeas corpus, pieces of reportage, and files from clandestine detention centres and on enforced disappearances), a compilation will be made with information regarding the disappearance of children and the imprisonment and/or abduction of pregnant militants in an attempt to describe the situation of apprehension and incarceration, the historical context, and the repression forces involved in the operation of arrest, kidnapping and/or torture of militants, children, and teenagers. Besides this heritage, a documental research will be made at Terror Archives, the Centre for Documentation and Archives for the Defence of Human Rights (CDyA) of Paraguay Supreme Justice Court, which contains a register of Alfredo Stroessner's thirty-five-year-long military dictatorship in Paraguay. The main argument in this research states that the archives from the Committee for the Defence of Refugees Human Rights from the Southern Cone, available at Fundo Clamor, contribute significantly to the rescue of historical memory from the dictatorial period and to the achievement of complete citizenship in these countries, considering that Brazil was the protagonist of the National Security Doctrine implantation process in South America.

Keywords: southern cone dictatorship, human rights, fundo clamor

\section{Introduction}

Two children, (1) Anatole Boris Grisona Julien, born at 9/22/72 in Uruguay, and (2) Eva Lucia Grisona Julien, born in Argentina at 05/07/75, at 09/26/76 they were kidnapped in Buenos Aires during an operation organized by police from Uruguay and Argentine. After some years, these kids were found in the city of Valparaiso, Chile. They were fine. Their

\footnotetext{
*Translated by Virgínia Starling. This article was developed during post doctoral stage of history, the Federal University of Minas Gerais, Brazil and supervised by Professor Heloisa Maria Starling Murgel, Ph.D. and Professor, Department of History, Faculty of Philosophy and Humanities (UFMG); main research fields: Republic Project: Core Research, Documentation and Memory. Email: starling@fafich.ufmg.br.

Anna Flávia Arruda Lanna Barreto, Resident post-doctoral fellow in the Graduate Program of the Federal University of Minas Gerais, Brazil; Ph.D. in History (UFMG), Adjunct teacher at UNA University Center, Brazil; main research fields: History, Documentation, and Memory. Email: annaflav@prof.una.br.
} 
parents, Roger Julien Caceres (Uruguay) and Victoria Grisona (Argentina), kidnapped in the same operation, are still disappeared. The entire family was kidnapped from their residence at Party San Martín, Buenos Aires Province. ${ }^{1}$

The text above refers to a denunciation made by the Committee in Defence of Human Rights for Southern Cone Countries-CLAMOR, ${ }^{2}$ in 1979, about the disappearance of Uruguayan children Anatole Boris Julien Grisona (4 years old) and Eva Lucía Victoria Julien Grisona (1 year and 4 months old), who were abducted on 26th September, 1976 together with their parents in Argentina and illegally deported to Chile. During the kidnapping operation, the children's parents were murdered and their offspring were taken to interrogation centres. Subsequently, they were abandoned in a square in the city of Valparaíso (Chile) and handed over to an orphanage by a social assistant who was passing by. ${ }^{3}$

From September 1976, Anatole's and Eva Lucía's relatives began a desperate search to meet the children again. According to historian Ananda Simões Fernandes, this practice is about a "State Terrorism modality of National Security dictatorships," ${ }^{4}$ especially in Argentina, where the alarming number of 230 children $^{5}$ was kidnapped during the military regime (1976-1983).

The advance of denunciation and research in this area points to the practice of this "state terrorism" modality in other Southern Cone countries. Data from the Human Rights Special Office in Brazil shows the following numbers as balance of Southern Cone's dictatorships:

In Brazil there were 50 thousand prisoners, 20 thousand tortured, 356 killed and missing, 4 children probably abducted. In Uruguay there were 166 missing people, 131 killed, 12 abducted babies, 55 thousand prisoners. In Paraguay there were from one thousand to two thousand dead and missing, 1 million in exile. In Chile there were 1,185 missing, 2,011 dead (although unofficial statistics show up to 10 thousand murdered), 42,486 political prisoners just in 1976. In Argentina there were 30 thousand killed and missing and 230 abducted children. ${ }^{6}$

In the Argentinean case, the majority of kidnapped children had their identities omitted and were subsequently illegally adopted by families directly or indirectly connected to the repression. An example of this situation is the story of Mariana Zaffaroni, abducted when she was eighteen months old, together with her parents Jorge Roberto Zaffaroni Castilla and María Emilia Islas de Zaffaroni in Buenos Aires on the 27th of September, 1976 by Argentinean and Uruguayan repression forces. From this date, Mariana's relatives began a search to find her. On the 20th of May 1983, the Argentinean newspaper "Clarin" from Buenos Aires published an appeal with the girl's photograph requesting from whoever had any information about her to get in touch with Abuelas da Plaza de $\mathrm{Mayo}^{7}$ or with Clamor group in São Paulo. Twenty days after the appeal, an anonymous letter arrived from Argentina to the Clamor group. This letter informed that Miguel Angel Furci, a member of the State Intelligence Service (SIDE), was supposed to be with Mariana in a suburb of Buenos Aires. The girl had been registered, two years after her birth, as a legitimate daughter of the Furci couple.

Cases like these became state politics in Argentina and were widely adopted in the other Southern Cone countries and in Brazil with cooperation of repression forces from these countries. Usually, children and teenagers were kidnapped with their parents, when the latter were arrested and/or abducted. An example of this situation is the story of Brazilian Maria Auxiliadora de Almeida Cunha Arantes, who was kidnapped in her house on the 13th of December 1968, the same day when the Institutional Act Number Five was issued, in Pariconha, countryside of Alagoas, together with her children André (3 years old) and Priscila (2 years old). She and several other children and teenagers were arrested and, sometimes, tortured with their parents, as is the case of teenager Ivan Seixas (16 years old), son of paranaense worker Joaquim Alencar de Seixas. Both were 
arrested on the 16th of April, 1971, and taken to the 37th Police Station and afterwards to the Department of Information Operations/Center for Internal Defence Operations of São Paulo (DOI-CODI/SP). Both were militants from Tiradentes Revolutionary Movement (MRT) at the time they were arrested. Father and son were tortured together and after Joaquim Alencar de Seixas was murdered, his house was invaded and his wife and daughters were arrested. Ivan spent six years in prison without standing trial.

The story of the "accursed babies," supposedly kidnapped by the Brazilian army, is told by inhabitants of the Araguaia region elucidates these cases of human rights violation and children abduction in Brazil. According to statements by the elderly people who live in the Araguaia region, these missing children were sons and daughters of women that had had relations with guerrillas and had nothing to do with the armed conflicts. José Maria Alves da Silva's testimony, a former Army guide, given to the newspaper O Estado de São Paulo on the 14th of July 2009, confirms this story about the abduction of children by the military forces.

On the 30th of September 1969, Virgílio Gomes da Silva Filho was arrested with his mother and his two brothers. On the previous day, his father Virgílio had been captured by repression agents and murdered. His mother and brothers were arrested while staying at a beach house in São Sebastião/SP. At the time, his elder brother Vlademir was eight years old, Virgílio was six and Isabel, his younger sister was only four months old. They were detained at the headquarters of Bandeirantes Operation (OBAN). The three children were torn away from their mother Ilda and taken to the Office of Juvenile Justice, where they remained for two months. They went through several interrogatories before that. Ilda stayed in prison until 1979, being out of touch most of the time. The children were separated and each of them went to live with an uncle. Sometimes they would reunite and stand in front of a post where their mother, still in prison, could see them. After being freed and reunited with her family, Ilda and her children left to live in Cuba, where they remained until they had concluded their studies at university. ${ }^{8}$

The story of Criméia Schimit de Almeida's arrest, mother of João Carlos Gradois, reveals one more episode of this history of imprisonment, abduction, and torture of children in military jails. Imprisoned at Bandeirantes Operation's buildings in São Paulo when she was eight months pregnant of João Carlos, Criméia was submitted to spankings and electrical shocks. After she had given birth, she remained imprisoned with the baby for fifty-two days.

Carlos Alexandre Azevedo died on February 19, 2013, in São Paulo. He was tortured when he was only a year and eight months old at the State Department of Political and Social Order (Deops) in 1974. Carlos was journalist Dermi Azevedo's son, militant and a founder of the Human Rights National Movement (MDNH). On the 14th of January, 1974, Carlos Alexandre and his mother were taken to the São Paulo headquarters of Deops, where his father was imprisoned. During Dermi's interrogation the policemen threw Carlos Alexandre on the ground and hit his head. Carlos suffered from after-effects of the torture and had to submit himself to treatments with antidepressants and antipsychotics for the rest of his life. On the 19th of February this year Carlos Alexandre put an end to his life with a drug overdose. ${ }^{9}$

Actions like these were used as interrogation techniques to get information that was considered essential to the National Security State in force in Southern Cone countries and in Brazil. As the Nunca Mais (Never More) report from Argentina denounces:

Because I answered negatively, they started kicking my companion with a belt, they pulled her hair and kicked little Celia Lucía, who was 13, Juan Fabián, eight, Verónica Daniela, three, and Silvina, only twenty days old.... The children were being pushed and shoved and asked if friends ever went to the house. After mistreating my companion, they grabbed the 
twenty-day-old baby; grabbed her feet, turned her upside down, and began hitting her, shouting at her mother: “... if you do not speak, we will kill her." The children cried and the terror was great. The mother begged them, screaming, not to touch the baby. Then they decided to do the "wet submarine" on my companion in front of the children, while they took me to another room. Until today, I know not what became of my companion.... ${ }^{10}$

None of the children who had their parents assassinated, clandestine or incarcerated have had the right to enjoy a family, school, or communitarian life. Their relationships were marked by secrecy and restrictions. Weekends were spent in prisons, the only occasions when they could visit their parents.

There are still cases in which pregnant women were abducted and after the occurrence of the birth, usually at clandestine centres, the children were taken away from their mothers with the false information that they would be delivered to their grandparents. After the separations the mother would generally be executed.

Several of the children born in captivity are still missing. This repressive methodology was adopted in Latin America's Southern Cone countries as a strategy to feign a culture of fear and uncertainty, a resource to intimidate the opponents of dictatorial regimes in Southern Cone countries.

In the end of the 1970s, when the Brazilian military dictatorship announced their first measures of mitigation, military regimes from Southern Cone (Argentina, Uruguay, Paraguay, and Chile) practiced recrudescence measures of authoritarianism and intensification of repressive apparatus. Arbitrary arrests, summary executions of political activists, exile, political banishments, housebreaks, abductions, and disappearing of children whose parents were political activists or opponents of the regime were practices which endorsed political repression in Southern Cone countries and usurped the human rights from thousands of Brazilians, Chileans, Argentineans, Paraguayans, and Uruguayans.

Our attention turns itself to the cases of disappeared, abducted, arrested, and tortured children whose parents were political activists or opponents of dictatorships from Brazil or Southern Cone countries, registered at the Committee in Defence of Human Rights for Southern Cone Countries-Clamor, from the Documentation and Scientific Information Centre-CEDIC-Pontifical Catholic University of São Paulo/SP, between the years of 1970 and $1992 .^{11}$

Fundo Clamor is distributed among 106 archive boxes, 28 files for periodicals, and one architect file. It brings together textual, oral, and iconographic documents. The documents were acquired through a donation from the Ecumenical Centre of Services to Evangelization and Popular Education (CESEP) in 1993.

The denunciations, correspondence, and testimonials that arrived at Clamor, above all from Uruguay and Argentina, are terrifying. The highlights of the main acts of violence committed by repression forces are assassinations, torture, disappearance, and abduction of relatives of political activists, especially of children whose mothers were pregnant activists arrested by the police of these countries or through the assembled action of repression forces of Southern Cone countries, usually administered by members of Operation Condor. ${ }^{12}$ According to reports and testimonials registered at Fundo Clamor, there were adoption lists at prisons for the babies that were born from women who had been arrested during their pregnancy. The women were tortured and were killed after having given birth. Their children were offered for adoption, a great number of them to families of militaries. In the whole, the Committee helped to locate seven missing children.

The Committee has conducted many investigations in order to verify cases of missing children and has collaborated on the solution of several of them. This work allowed the group to get in touch with a group of ladies known as Abuelas de la Plaza de Mayo, founded in 1979 in Argentina. They were women who had started a fight for the defence of life and for the right to keep members that shared the same blood united. These 
grandmothers became known throughout the world as a symbol of the struggle against the dictatorship in defence of human rights and of the right to live once again with their grandchildren.

The abduction of children of political prisoners and the appropriation of their identities establish themselves as crimes against humanity and are, therefore, imprescriptible. Thus, to research this subject is to guarantee that arbitrariness like these will not go unnoticed by societies victimized by dictatorial governments, above all where these disappearances, imprisonments, and torture were most frequent. To study this subject is to guarantee the relatives of victims of enforced disappearances the right of knowledge and memory of facts that, in a stark and brutal way, took children and teenagers away from family life, who were innocent victims of this "State terrorism."

The main argument in this research consists of the statement that the archives from the Committee in Defence of Human Rights for Southern Cone Countries, available at Fundo Clamor, contribute significantly to the rescue of historical memory from the despotic and dictatorial period in Brazil, Argentina, Chile, Paraguay, and Uruguay, as well as the knowledge of involvement of Brazilian military authorities in the assembled action performed with Southern Cone countries in the process of imprisonment, abduction, torture, and disappearance of thousands of political activists and their relatives.

There is an agreement in historiography about Brazil's leadership in actions of support and maintenance of dictatorships set up in the Southern Cone after 1964. This leadership included actions of repression, especially information exchange, document supply, prisoner exchange, training in the area of intelligence, and "interrogation" techniques with the collaboration of American and British secret services. Historiography analyzes that this process has expanded and intensified itself in the course of almost 20 years and identifies at least three distinct stages of collaboration between the dictatorships, with Brazilian participation. The first stage begins in 1964; the second, after the beginning of the Chilean dictatorship, includes prisoner exchange without register, abduction, and assassination. The third stage, the Condor, is from 1975. Acervo Clamor is important because it allows analysis and awareness of these actions and the Brazilian leadership in them.

\section{Methodology}

The methodology used in this descriptive and qualitative research embraces two directions: a bibliographical and a descriptive analytic documental research.

Because it is a descriptive-qualitative research, this work seeks to describe the cases of abduction, imprisonment, and disappearance of children whose parents were political activists during the period of dictatorial governments in Southern Cone countries-Argentina, Paraguay, Chile, Uruguay-and in Brazil. Through the consultation to Fundo Clamor (correspondence, denunciations, bulletins, leaflets from Abuelas de la Plaza de Mayo, reports, writs of habeas corpus, and files on enforced disappearances), documents will be selected that have information about the disappearance of children and/or the imprisonment and abduction of pregnant activists, seeking to describe the situation of apprehension and incarceration, historical context, the repression forces involved in the imprisonment operation, abduction, and/or torture of female activists and children involved.

The criteria used to the fulfil the bibliographic research will be based on the use of specific bibliography about human rights, about historical memory and history of present time, about dictatorships in Brazil, Argentina, Paraguay, Chile, and Uruguay, and about joint repression operations performed by military authorities from Southern Cone countries. 
Aiming the viability of the research and to answer the question-in what measure does Fundo Clamor contributes to the rescue of historical memory about the violation of human rights of children and teenagers whose parents opposed dictatorial regimes in Southern Cone countries and in Brazil?-We have used documental research, by means of data collection through analysis of documents, records, and information available at Fundo Clamor.

The board is composed of monthly and annual assessments of the activities developed by organizations in defence of human rights, accounts of conferences on political prisoners and missing persons and about clandestine interrogation centres, files on victims of enforced disappearances and on torturers, correspondence about imprisonments and disappearances that happened in Latin America, subscription forms to publications, dossiers on political detainees and victims of enforced disappearances, lists of prisoners and missing peoples' names, monthly assessments of the repressive situations that occurred in the Southern Cone, posters about the imprisonments and forced disappearances in several countries in South America, posters about events in defence of human rights, catalogues of publications for sale, texts of study and reflection about human rights violation, lists of political prisoners in Chile, lists of statistics in prisons and forced disappearances in Latin America, speeches, reports of Campaigns in favour of human rights, texts about the participation of Human Rights organisations in Chile, Argentina, Uruguay, and Paraguay, meetings' resolutions, primers about human rights, travel reports around Latin America, folders that publicized missing children, lawyers' appeals before the Justice Court, features on victims of enforced disappearances and political prisoners, manifestos from relatives against the impunity enjoyed by the State and its employees, books and leaflets about human rights, and its violation and periodic publications from several organisations that dealt with human rights defence in Latin America.

The primary retrospective sources present in the Fundo Clamor archives are intended to be used as documental sources, such as, minutes of meetings, flyers, bulletins, primers, newspapers, and publications from the Committee, received correspondence and denunciations, meeting's resolutions, reports, mapping of the main activities developed by the Committee and of the refugees attended to by the Committee, and newspapers from the great press. This information shall be obtained through systematic observation of the documentation made available by the board.

Other than this document collection, the patrimony of the Terror Archive at Centro de Documentación $y$ Archivo para la Defensa de los Derechos Humanos (CDyA), from the Supreme Justice Court in Paraguay, has also been consulted. It is a register of around 60,000 documents collected in the course of 35 years' general Alfredo Stroessner's dictatorship. They are police files, lists of the prisoners' entries and exits, notes by the investigations chief, confidential assessments, control of political parties, periodic publications, lists of suspects, information about associations and groups which were considered subversive, syndicates control, and objects such as books and identity cards. Within this archive, special attention is given to the images of microfilm 143 that contain the record of activities of Operation Condor in Southern Cone countries and in Brazil.

\section{The Repression in Southern Cone Dictatorships}

ARTICLE 1. Men are born and remain free and equal in rights. Social distinctions may be based only on considerations of the common good.

ARTICLE 2. The aim of every political association is the preservation of the natural and imprescriptible rights of Man. These rights are Liberty, Property, Safety and Resistance to Oppression. 
ARTICLE 3. The principle of any sovereignty lies primarily in the Nation. No corporate body, no individual may exercise any authority that does not expressly emanate from it.... (Declaration of Human and Civic Rights, 26 of August, 1789)

Paradoxically, after more than two centuries, the promise of Human Rights universality still faces many difficulties to its effectuation. After years of summary disrespect for South-American human rights, especially during civil and military dictatorships which counted on varied coups d'état and the seizure of power, on the hideous practice of torture, disappearance, abduction, and identity concealment of thousands of political activists who stood out against the regimes, several citizens, relatives of victims of enforced disappearances, still await effective equality of rights to memory, to knowledge of facts, and to the identification of the beloved ones. In that context, the disrespect for human rights had a specific target: All those who politically and ideologically opposed the dictatorships established in Southern Cone countries (Argentina, Chile, Uruguay, Paraguay) and in Brazil.

The action of repressive forces from these countries sought, by manipulating the means of communication and education to silence any manifestation that was contrary to economical, political, and ideological interests for partisans of dictatorships established after the second half of the 20th century. The abduction and disappearance of political opponents and their children was part of a deliberate and organized armed scheme, which counted on the assembled contribution of the armed forces from the other Southern Cone countries and Brazil, to the denunciation, the abduction, and the disappearance of bodies.

According to the ideology of geopolitical essence depicted in the National Security Doctrine, ${ }^{13}$ the enemy was hunted and eliminated. The repressive military apparatus was used against the population, especially against the subversive and the urban guerilla. The progressive and revolutionary speech of civil society was progressively replaced, or better, "silenced by the conservative uproar, by the voice of Order, Morality, Country, and Family." 14 Civil and military coups in Southern Cone countries, in the second half of the 20th century, disrupted the revolutionary perspectives of opposing branches in civil society that dreamed with the construction of a new society. Socialist moods were silenced by the speech of Order and National Security, tradition, family, and prosperity. Social and student movements and progressive sections of civil society, stupefying, went from euphoria to doubt, from offense to retreat. ${ }^{15}$

It is worth emphasizing that civil society's growing discontent in Southern Cone countries and Brazil was in the context of Cold War, in a world marked by ideological bipolarity amongst the blocs led by the United States of America (USA), that sponsored capitalism, and by the Union of Soviet Socialist Republics (USSR), that defended socialism. It is important to highlight in this context the impact caused in the USA by the Cuban Revolution in 1959, which implanted a socialist regime in a country geographically close to the USA. With the establishment of socialism in Cuba, the interests of leaders from the USA and from Southern Cone countries are threatened by an ideology contrary to North-American and military interests, whose socialist and revolutionary principles questioned the pillars that sustained the economic development of these sectors. USA's interests in Latin America had been shaken since the Cuban Revolution that led "the superpower country to consider the internal politics from each country in the region as an extension of its own external politics."

The Cold War between USSR and USA that dominated the international scenario during the second half of the 20th century had entire generations growing under the shadow of global nuclear wars, which, as they believed, could start at any moment and devastate mankind. The fear of the inevitable mutual destruction would 
prevent a side or the other to signal the planned suicide of civilization. The peculiarity of the Cold War was that, objectively, there was no imminent danger of a world war.

To Latin America, the greatest impact of Cold War was not the nuclear weapons or the arms race, but the "counterinsurgency war," based on the National Security Doctrine, which aimed to eliminate possible social revolutions in areas submitted to ideological influence from the USA. According to the Secretary of the Kennedy government, Robert McNamara, three types of war were being considered in that context of Cold War: atomic war, conventional war, and non-conventional war. This last type of war was interpreted as a strategy of the International Communist Party to conquer followers to socialism. To this effect, the new challenge to the USA was to stop non-conventional or revolutionary war through the establishment of the National Security Doctrine and the dictatorial regimes in South America. ${ }^{17}$

\section{Committee in Defence of Human Rights for Southern Cone Countries-CLAMOR}

"Clamor" group is a civil, informal, and clandestine organisation, created in the end of 1977 with the support of Cardinal Archbishop Dom Paulo Evaristo Arns, in the city of São Paulo. This organisation aimed to denounce the violation of human rights that had been happening in Latin America, especially in Brazil, Uruguay, Argentina, Chile, and Paraguay, besides providing assistance for refugees and for the politically persecuted.

The name "Clamor" was given to the bulletin from the Committee in Defence of Human Rights for Southern Cone Countries, whose first volume was published in June 1978. The name "Clamor" was inspired by the Psalm (88: 2) - "LORD, you are the God who saves me; day and night I cry out to you. Let my prayer enter into thy presence; incline thine ear unto my cry." The intention the Committee's founders had was to emphasize one of its main characteristics: to denounce the continual violations of human rights that occurred in Latin America.

The bulletin created by the Committee was published in three languages-Portuguese, Spanish, and English, and sent without being signed to 22 Brazilian states (press), to 23 American countries (Latin-American entities of Human Rights), and to 25 countries in other continents (European and North-American entities). Throughout twelve years of existence, the Committee published 17 numbers of the bulletin. Amongst the subjects it approached, the following stand out among others: human rights violations in Southern Cone countries, the people's struggle to denounce and defeat military regimes, the situation of prisons, the treatment given to prisoners, and pertinent legislation for refugees. The Committee received a budget from the World Council of Churches so that it could maintain the Bulletin.

In 1978, when it was founded, the Committee was composed of three people connected to human rights defence-Jan Rocha, Luiz Eduardo Greenhalgh, and Jaime Wright. The three met in São Paulo to verify the possibility of publicizing the atrocities committed against human rights of Argentineans, Uruguayans, Paraguayans, Chileans, and Brazilians during the military regime in these countries. They searched for Cardinal Archbishop Dom Paulo Evaristo Arns to communicate the massive arrival of political refugees who told unknown stories of disrespect to human rights. Dom Paulo welcomed the idea and requested that the Committee, for security reasons, remained linked to the Archdiocesan Pastoral Committee for Human Rights and Marginalized from the Archdiocese of São Paulo. At that moment, the Committee in Defence of Human Rights for Southern Cone Countries was born. 
The image that marked Clamor's symbol was a drawing of a flame that shines through prison grates, created by political prisoner Manoel Cirilo de Oliveira Neto, who was freed in 1979. Other than the symbol, the Committee also had a slogan: "Human Rights have no borders." With this slogan the Committee traversed every country in the Southern Cone and sought financial and political aid from international organisms such as the World Council of Churches, Amnesty International, the United Nations, and the World Bank.

According to accusations made by political activists and by members of Clamor group, Brazil not only exported its knowledge of police and military violence, but it was also part of a connexion with other repressive forces situated in Southern Cone countries. A proof of that would be the existence of computers with terminals linked to the main airports in the continent in order to follow the movements of all of those considered subversive or enemies of the Nation.

According to Jamie Wright, three elements were crucial for the efficacy of the Committee's work: concrete actions without ideological or partisan theorizations, ecumenical orientation, and a minimum of institutional structure, so that they could guarantee agility and flexibility for the team's actions. As the years went by, new members were integrated into the Committee. Clamor's members took turns at the office, located at 890 Higienópolis Street, room 19, São Paulo/SP. Meetings between members happened once a week to define the tasks they should perform.

The Committee's initial goal was to give assistance to refugees who were not recognized by the United Nations High Commissioner for Refugees (UNHCR), something that could compromise its personal security for.

The Clamor group put pressure on Southern Cone governments to free political prisoners and to publish paid features requesting information about missing children whose parents were political activists. It sent its members to investigate denounces and disappearances of children and activists. Two facts ought to be highlighted in relation to the group's actions: One was at the time when the committee delivered a list of Brazilian victims of enforced disappearances to the North American president, Jimmy Carter, while he was visiting Brazil in 1978; and the other was in 1980, when the Committee delivered a list of victims of enforced disappearances from Southern Cone countries to Pope John Paul II, also during his visit to Brazil.

One of the greatest works done by the Committee was the systematisation of a list of victims of enforced disappearances in Argentina, which subsequently originated the book "Desaparecidos de la Argentina," published in 1982. The book gathered information on 7,791 missing people in Argentina.

In the 1980s, with political openness and the consequential end of military regimes in the Southern Cone region, the Clamor group gradually lost its function of protecting and assisting political refugees and terminated its activities in 1991.

\section{Final Considerations}

The reason why we have made this study arose from the verification that, in spite of the incentive from the Brazilian federal government to rescue historical memory, especially from the period of the Brazilian Military Regime, the obstacles and prejudices which are part of the routine of investigations and academic research in the area are still a lot. We believe that the rescue of content from this board and of others which are similar is crucial to the perception of the cooperation politics adopted between Southern Cone countries and Brazil, as well as of the Brazilian leadership in actions of repression, prisoner exchange, and training on intelligence areas and interrogation techniques. 
Brazilian military repression consisted in the institutionalization of torture and interrogation techniques, as well as in the development of actions and advertisements that made visible the existence of repressive apparatus in the country. To this effect, besides physical repression, the groups that opposed the Military Regime had to live with constant ideological and psychological intimidation, promoted by the repression campaign. ${ }^{18}$

According to the logic of dictatorial regimes established in Brazil and Southern Cone countries, being an informant working for the dictatorship was the same as being a patriot defending the nation. The assimilation of the National Security Doctrine by militaries took nationalism for a synonym of anti-communism as a component of the capitalist ideology from the Cold War promoted by the United States. The Alliance for Progress, set in the 1960s by president John F. Kennedy and the other countries in South America, gave an economic impulse to military governments in these countries, so these governments became imponderable allies with the United States.

The originality of the research lies in the production of academic work in the area of History that seeks to analyse the information in Fundo Clamor as a contribution to the rescue of historical memory from the period of political and military authoritarianism in Southern Cone countries and Brazil, especially in what relates to abduction, disappearance, and identity appropriation of hundreds of children and teenagers, sons, and daughters of political opponents of dictatorial regimes established in Southern Cone countries and Brazil.

We believe that the reconstitution of that period's memory (1970-1992) through the analysis of Fundo Clamor's archives will allow a fundamental historiographical research for the recovery of a history silenced by despotic speeches from political and military repression organisations.

Therefore, it is a research about the reasons, passions, and implicit desires in people's struggles in defence of human rights of refugees who, due to their political convictions, were usurped of their human and civil rights during a period of political authoritarianism. To tell this story is to tell episodes of fights in defence of human rights, but also episodes of usurpation of these rights, with clandestine, although explicit, methods of barbarism, of physical violence, psychological, and cultural, capable of generating a culture of fear fed by the State terrorism effective in these countries. To tell this story is to offer the present and future generations the chance to know their past, their leaders, and their armed forces, whose maximum function is to defend the nation. To know this story is to guarantee the remembrance of facts that dishonoured humanity, that fed silence and political and social inaction. To remember these facts is to offer society the chance to know its past, learn with it and, from that, draw its future. After all, according to the psychologist Eclea Bosi, "one of the most cruel exercises of oppression is the spoliation of memories"(Eclea Bosi 1979, 362).

\section{Notes}

1. Boletín de Prensa del 31/07/1979. Fundo Clamor, file 1, plastic 60. Archive of the Committee in Defence of Human Rights for Southern Cone Countries, from the Documentation and Scientific Information Centre-CEDIC-Pontifical Catholic University of São Paulo/SP.

2. Committee for the Defence of Refugees Human Rights from the Southern Cone created in 1977, supported by the Archbishop of São Paulo-Cardinal Paulo Evaristo Arns and associated to the Archdiocesan Pastoral Committee for Human Rights and Marginalized. Its aim was to protect and assist refugees from Southern Cone countries-Argentina, Brazil, Chile, Paraguay, and Uruguay.

3. On this subject refer to: LIMA, Samarone. Clamor: the victory of a Brazilian conspiracy. Rio de Janeiro: Objective, 2003.

4. Fernandes, Ananda Simões. "This war isn't against children": child abduction during the dictatorships of the Southern Cone National Security In: PADROS, Enrique Serra; NUNES, Carmen Lúcia da Silveira; LOPES, Vanessa Albertinence; 
FERNANDES, Ananda Simoes (Eds.). Memory, Truth and Justice: marks of the dictatorships of the Southern Cone. Porto Alegre: ALRS, 2011. p. 48.

5. BRAZIL. Presidency of the Republic. Special Secretariat for Human Rights. Right to Memory and Truth: Stories of Girls and Boys Marked by Dictatorship/Special Secretariat for Human Rights. Brasilia: Special Secretariat for Human Rights, 2009.

6. BRAZIL. Presidency of the Republic. Special Secretariat for Human Rights. Right to Memory and Truth: Stories of Girls and Boys Marked by Dictatorship/Special Secretariat for Human Rights. Brasilia: Special Secretariat for Human Rights, 2009. p. 101 .

7. Argentinean human rights organisation, established in 1977, that has as a purpose locate and restore to their families every children that was abducted and went missing during the last military dictatorship in Argentina (1976-1983).

8. Pimenta, Edileuza; Teixeira, Edson. Virgílio Gomes da Silva: From Leaving Work to Guerrilla. Sao Paulo: Editorial Plena, 2009.

9. Dies in Sao Paulo man tortured by the dictatorship when he was one year. Retrieved March 1, 2013, from $<$ http://noticias.terra.com.br/brasil/,ead367d062fec310VgnVCM3000009acceb0aRCRD.html>

10. CONADEP. Never Again: Report of the National Commission on the Disappearance of Persons in Argentina. Porto Alegre: L\&PM, 1986. 230.

11. Documentation period of Fundo Clamor archives.

12. Assembled action of repression forces from Brazil, Argentina, Chile, Bolivia, Paraguay, Uruguay, created in 1975. This operation's main function was to neutralize and repress groups that opposed the military regimes settled in South America. The operation's name refers to an Andean bird, symbol of astuteness in the hunt to its preys.

13. About the complex ESG/IPES/IBAD, National Security Doctrine and its role in the 64 coup, refer to: Toledo, 1977; Dreifuss, 1981; Starling, 1986; Sodré, 1992.

14. Holanda, Heloísa Buarque e Gonçalves, Marcos. Culture and Participation in the 60s. São Paulo: Brasiliense, 1985. 14.

15. About the degree of radicalization of the Brazilian Military Regime, between 1964 and 1968, refer to: Fon, 1979; Arquidiocese, 1987; Alves, 1989.

16. Padrós, Enrique Serra. Like the Uruguay there isn't another ... Terror of State and National Security. Uruguay (1968-1985): From Pachecato to civil-military dictatorship. 2005. 434 f. Thesis (Ph.D. in History) Institute of Philosophy and Human Sciences, Federal University of Rio Grande do Sul, Porto Alegre: UFRS, 2005. 47.

17. Reis, Ramiro José dos. Operation Condor and the Hijacking of Uruguayans in the streets of a not very happy seaport. 2012. $184 \mathrm{f}$. Thesis (MA in History)-Faculty of Philosophy and Human Sciences, Federal University of Rio Grande do Sul, Porto Alegre, 2012. 34.

18. About the dead and victims of enforced disappearances during the military regime, refer to: Archdiocese of Saint Paul (1987) Dossier of dead and missing politicians since 1964 (1995).

\section{Works Cited}

Alves, Maria Helena Moreira. State and Opposition in Brazil (1964-1984). Petropolis: Voices, 1989.

Andrade, Ana Célia Navarro. Inventory Cry Fund: organization and description of the Fund Committee for the Defense of Human Rights for the Southern Cone countries-Faculty of Philosophy, Letters and Human Sciences, University of São Paulo, São Paulo, 2000.

Arantes, Maria Auxiliadora de Almeida Cunha. "Pain and Helplessness: Children and Parents 40 Years Later." Clinical Psychology, Rio de Janeiro 20.2 (2008): 75-87.

Arquidiocese de São Paulo. Brazil, Never Again. 11th ed. Petrópolis/RJ: Voices, 1987.

Assunção, Luis Fernando. Murdered by the dictatorship. Santa Catarina: Insular, 2004.

Autopsy Shadow. Veja Magazine 18 (1992): 20-32.

Bauer, Caroline Silveira. A Comparative Study of the Practical Disappearance of the Argentine and Brazilian Civil-Military and Policy Memory Dictatorships in Both Countries. 2011. 446f. Thesis (Ph.D. in History and History Contemporania)-Federal University of Rio Grande do Sul and Universitat de Barcelona, Porto Alegre, 2011.

Bosi, Ecléa. Memory and Society: Memories of old. São Paulo: Queiroz TA, 1979.

Brazil. Presidency of the Republic. Special Secretariat for Human Rights. Right to Memory and Truth: stories of girls and boys marked by dictatorship. Brasilia: Special Secretariat for Human Rights, 2009.

Brazil. Special Secretariat for Human Rights. Special Commission on Political Deaths and Disappearances. Right to Memory and Truth. Brasilia: Special Secretariat for Human Rights, 2007.

Cerveira, Neusah Romanzini Maria Pires. Memory of Pain: Operation Condor in Brazil (1973-1985). 2007. 340f. Thesis (Ph.D. in Social History)-Faculty of Philosophy, Letters and Human Sciences, University of São Paulo, São Paulo, 2007.

CHILBOM/CONDOR, 28/09/1976. Available at: <http:/www.gwu.edu/ nsarchiv/NSAEBB/NSAEBB8/ch23-01.htm> Acess on: Feb.16, 2013. 
Commission Special on Political Deaths and Disappearances. Right to Memory and Truth. Special Secretariat for Human Rights of the Presidency. Brasilia, 2007

Conadep. Never Again: Report of the National Commission on the Disappearance of Persons in Argentina. Porto Alegre: L \& AM, 1986.

Cunha, Luiz Cláudio. Operation Condor: kidnapping of the Uruguayans: A story of the times of the dictatorship. Porto Alegre: L \& AM, 2008.

D' Araújo, Maria Celina, Ed. Years of Lead: military crackdown on the memory. Rio de Janeiro: Relume Dumará, 1994.

Die in Sao Paulo man tortured by the dictatorship when he was one year. Available at: $<$ http://noticias.terra.com.br/brasil/,ead367 d062fec310VgnVCM3000009acceb0aRCRD.html> Access on Mar. 1, 2013.

Dimenstein, Gilberto. Democracy in Pieces: human rights in Brazil. Sao Paulo: Companhia das Letras, 2006.

Dingers, John. The Condor Years: a decade of international terrorism in the Southern Cone, Sao Paul: Cia das Letras, 2005.

Documentation and Archive Centre for the Defence of Human Rights (CDYA). Available at: <http://www.aladin0.wrlc.org/gsdl/co llect/terror/terror_s.shtml> Acess on: Mar. 4, 2013.

Dossier Of The Dead And Missing Politicians since 1964. Recife: Company of Pernambuco, 1995.

Dreifuss, René A. 1964: The Conquest of the state. Political Action, Power and Class Coup. Rio de Janeiro: Voices, 1981. Army took 4 babies from Araguaia, say former military guide. O Estado de São Paulo, São Paulo, Jul.14 2009. Available at: $<$ http://www.estadao.com.br/noticias/impresso,exercito-levou-4-bebes-de-guerrilheiros-diz-mateiro,402291,0.htm> Acess on: Feb. 11, 2013.

Fernandes, Ananda Simões. When the Enemy is Beyond the Frontier: The Repressive Connections Between Civil-Military Dictatorship in Brazil and Uruguay (1964-1973). 2009. 275f. Thesis (MA in History)-Institute of Philosophy and Human Sciences, Federal University of Rio Grande do Sul, Porto Alegre, 2009.

Fernandes, Ananda Simões. "This war isn't against kids": the abduction of children during the dictatorships of the Southern Cone National Security In: Padrós, Enrique Serra; Nunes, Carmen Lúcia da Silveira, Lopes, Vanessa Albertinence; Fernandes, Ananda Simoes, eds. Memory, Truth and Justice: the marks of the dictatorships of the Southern Cone Porto Alegre: ALRS, 2011.

Fico, Carlos, Marieta de Moraes FERREIRA, Maria Paulo Araújo, and Quadrat, Samantha Viz, eds. Dictatorship and Democracy in Latin America: historical perspective and balance. Sao Paulo: FGV, 2008.

Fico, Carlos. Big Brother, the Brother Sam Operating the Years of Lead: the U.S. government and the Brazilian Military Dictatorship. Rio de Janeiro: Brazilian Civilization, 2008.

Fico, Carlos. How They Acted, the Underground of Military Dictatorship: Espionage and Political Police. Rio de Janeiro: Record, 2001.

First Working Meeting of National Intelligence, 29/10/1975. Available at: $<$ http://www.gwu.edu/ nsarchiv/NSAEBB/NSAEBB23 9b/PDF/19751000\%20Primera\%20reunion\%20de\%20Trabajo\%20de\%20Inteligencia\%20Nacional.pdf $>$ Accessed on Feb. $16,2013$.

Fon, Antonio Carlos. Torture: The History of Political Repression in Brazil. Sao Paulo: Global Publisher and Distributor, 1979.

Goes, Walder de, and Aspasia Camargo. The Drama and the Succession Crisis of the Regime. Rio de Janeiro: New Frontier, 1984.

Gorender, Jacob. Fighting in the Darkness: The Brazilian Left: Lost Illusions of the Armed Struggle. Sao Paulo: Attic, 1987.

Grandmothers of Plaza de Mayo. Return of children. 1997. Available at: <http://www.pparg.org/pparg/documentos/represion/ana apropiacion/_b/contentFiles/RESTITUCION_DE_NINOS.pdf $>$ Acess on: Feb. 11, 2013.

Hobsbawm, Eric. About History. Sao Paulo: Companhia das Letras, 1998.

Hunt, Lynn. The Invention of Human Rights; Story. Sao Paulo: Companhia das Letras, 2009

Leitão, Matheus. “Tortured Before Being Born.” Magazine Era, São Paulo, February 15. 2007. Online edition available at: $<$ http://revistaepoca.globo.com/Revista/Epoca/0,,EDR76421-6014,00.html> Acess on: Feb.11, 2013.

Lima, Samarone. The Compartida Penumbra: Lone Resistance from Clamor Group against Dictatorships of the Southern Cone of Latin America (1978-1991). Dissertation (Masters in Latin American Integration)-University of São Paulo, São Paulo, 2000.

Lima, Samarone. Outcry: the Victory of a Brazilian Conspiracy. Rio de Janeiro: Objective, 2003.

Lopez, Miguel H. "Stroessner and I: Social Complicity with the Dictatorship (1954-1989)." In: Rollemberg, Denise; Quadrat, Samantha Viz. The Social Construction of Authoritarian Regimes: Legitimacy, Consensus and Consent in the Twentieth Century. Brazil and Latin America.Vol. 1. Rio de Janeiro: Brazilian Civilization, 2010. 437-70.

Netherlands, Heloisa Buarque, and Marcos Goncalves. Culture and Participation in the '60s. Sao Paulo: Brasiliense, 1985.

Oria, Piera Paola. From the House to the Square. Buenos Aires: New Latin, 1987. 
Oriental del Uruguay Republic. Presidency of the Republic. Historical Investigation on Missing Detainee. Montevideo: National Direction of Impresiones Oficiales y Publicaciones, 2007.

Padros, Enrique Serra et al. (Orgs). Memory, Truth and Justice: the marks of the dictatorships of the Southern Cone. Porto Alegre: Legislative Assembly of Rio Grande do Sul, 2011.

Padros, Enrique Serra. War Booty: ownership and disappearance of children during the civil-military regimes platinum 6.11 (2007): 141-61.

Padros, Enrique Serra. As el Uruguay no hay ... Terror of State and Homeland Security. Uruguay (1968-1985): From Pachecato to civil-military dictatorship. 2005. 434f. Thesis (Ph. D. in History )-Institute of Philosophy and Human Sciences, Federal University of Rio Grande do Sul, Porto Alegre: UFRGS, 2005.

Padros, Enrique Serra. "Operation Condor and the Repressive Connection in the Southern Cone: the fight for Truth and Justice." Organon 47 (2009): 115-38.

Padros, Enrique Serra et al. The Dictatorship of National Security in Rio Grande do Sul (1964-1985): history and memory. Porto Alegre: Corag, 2009.

Pereira, Anthony W. Dictatorship and Repression: authoritarianism and the rule of law in Brazil, Chile, and Argentina. New York: Continuum, 2010.

Perrone, Fernando. Prague, Sao Paulo, Paris 68, reports of wars. Sao Paulo: Busca Vida, 1988.

Pepper, Edileuza, and Edson Teixeira. Virgilio Gomes Da Silva: From a Leaving Worker to a Guerrilla. Sao Paulo: Editorial Plena, 2009.

Punta Rodulfo, Marisa. “Trauma, Memory and Historicizing: Children Missing Victims of Military Dictatorship.” In: Ulriksen de Viñar, Mauren (comp.). Social Memory: fragmentations y responsibilities. Montevideo: Trilce, 2001. 89-98.

Quadrat, Samantha Viz. "The Right to Identity: the restitution of appropriate children in the basements of the military dictatorships of the Southern Cone." History, Sydney 22.2 (2003):167-81.

Quadrat, Sandra Viz. "Memory, Human Rights and Politics in Contemporary Argentina." X Meeting of Regional History-ANPUH-RJ. History and Biographies-University of the State of Rio de Janeiro, 2002.

Reis, Ramiro José dos. Operation Condor and the Hijacking of Uruguayans in the Streets of a not Very Happy Seaport. 2012. 184f. Thesis (MA in History)-Faculty of Philosophy and Human Sciences, Federal University of Rio Grande do Sul, Porto Alegre, 2012.

Rollemberg, Denise, and Samantha Quadrat, eds. The Social Construction of Authoritarian Regimes: legitimacy, consensus and consent in the twentieth century-Brazil and Latin America. Vol. 1. Sao Paulo: Brazilian Civilization, 2010.

Sarlo, Beatriz. Present Time. Rio de Janeiro: José Olympio, 2005.

Sodré, Nelson Werneck. The reactionary Offensive. Rio de Janeiro: Brazil Bertrand, 1992.

Starling, Heloise. The gentlemen of the General: The New Conspirators and Blow 64. Petropolis: Voices, 1986.

Teubal, Ruth. La restitución missing-appropriate Code niños por la Argentine military dictator. Analisis of Algunos Psychological Aspects. Avaiable at: <http://rua.ua.es/dspace/bitstream/10045/5637/1/ALT_11_13.pdf> Accessed on: Feb. 11, 2013.

Toledo, Caio Navarro. ISEB: factory ideologies. Sao Paulo: Atica, 1977.

Vasquez, Ana, and Ana Maria Araujo. Exils Latin Américains: la malédiction d' Ulysse. Paris: L' Harmattan/CEMI, 1988.

Vera, Myriam González. "Happy Year" in Paraguay. Festival on November 3, birthday of Alfred Stroessener. In: Rollemberg, Denise, and Samantha QUADRAT, eds. The Social Construction of Authoritarian Regimes: legitimacy, consensus, and consent in the twentieth century-Brazil and Latin America.Vol. 1. Sao Paulo: Brazilian Civilization, 2010. 393-436.

Weffort, Francisco C. Why Democracy? 4th ed. Sao Paulo: Brasiliense, 1986. 